http://dx.doi.org/10.4314/bajopas.v12i1.35S

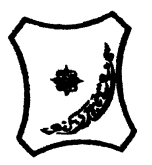

Bayero Journal of Pure and Applied Sciences, 12(1): 221 - 226

ISSN $2006-6996$

\title{
ENUMERATION OF TOTAL AND FEACAL COLIFORM BACTERIA OF SOME BOREHOLE WATER IN GOMBE, GOMBE STATE, NIGERIA
}

\author{
${ }^{* 1}$ Nuru Adamu Garkuwa, ${ }^{1}$ Sa'adatu Said Mustapha, ${ }^{2}$ Sani Aliyu Ibrahim, ${ }^{3}$ Muhammad \\ Yusha'u, ${ }^{2}$ Mansur Abdulrasheed and ${ }^{4}$ Usman Adamu Garkuwa \\ ${ }^{1}$ Department of Biological Sciences, Faculty of Science, Gombe State University, Gombe State \\ ${ }^{2}$ Department of Microbiology, Faculty of Science, Gombe State University, Gombe State \\ ${ }^{3}$ Department of Microbiology, Faculty of Life Sciences, Bayero University Kano, Nigeria \\ ${ }^{4}$ Department of Human Physiology, Bauchi State University Gadau, Bauchi State, Nigeria \\ *Correspondence Author: nuratoro@gmail.com, +2348065585642
}

\section{ABSTRACT}

Inadequate provision of potable drinking water in relation to teaming population is forcing most of the urban communities to drink untreated water obtained from traditional boreholes. Hence, the need to assess the portability of drinking water. In this research, boreholes water samples collected within Gombe city were investigated bacteriologically using multiple tube fermentation and pour plate methods to examine feacal coliform and coliform bacterial counts respectively; bacterial isolation was conducted using standard culture methods. Identification of the bacterial Isolates were carried out by macroscopic, microscopic and biochemical examinations. Total coliform bacteria ranges from $<3$ to $11 \mathrm{MPN} / 100 \mathrm{ml}$ and 1 to $3 \mathrm{MPN} / 100 \mathrm{ml}$ for faecal coliform. The borehole water samples from studied areas had high counts of faecal coliforms (Escherichia coli), and other pathogens like Entrobacter and Salmonella. The findings showed that all the borehole water analysed were not suitable for human consumption and may pose a serious threat to the health of consumers and therefore, there is need for treatment of these borehole waters by the borehole proprietors and also by simple treatment methods such as boiling, filtration before drinking and agitation by the consumers.

Keywords: Borehole water, Quality, Isolation, Identification, Coliform bacteria

\section{INTRODUCTION}

Microorganisms play a major role in water quality and the microorganisms that are concerned with water borne diseases are Salmonella spp, Shigella spp, Escherichia coli and Vibrio cholera (Adetunde and Glover, 2010). All these cause disease including; typhoid fever, diarrhea, dysentery, gastroenteritis, cholera. The most dangerous form of water pollution occurs when faeces enter the water supply. Many diseases are perpetuated by the faecal-oral route of transmission in which the pathogens are shed only in human faeces. Presence of faecal coliforms of $E$. coli is used as an indicator for the presence of any of these water borne pathogens. Larry (2006), suggested, that ground water contamination is the leading worldwide cause of deaths and diseases. It accounts for the deaths of more than 14,000 people daily, and the majority of them children under 5 years old (Larry, 2006). In recent years, the widespread reports of pollutants in groundwater have increased public concern about the quality of groundwater. Children are generally more vulnerable to intestinal pathogens. Steiner et al. (2006) reported that about 1.1 million children die every year due to diarrheal diseases.

The acute water shortage forced many people to drink untreated water obtained from surface and underground sources thereby exposing them to hazardous chemicals and infectious agents. This has made many researchers to focus their attention towards evaluation of physicochemical and microbial characteristics of water supplies (Adeyemi et al., 2007). Gombe Metropolis, the administrative capital of Gombe State provides a good study of the situation. Prior to 1996 when it was made the capital of the state, Gombe Metropolis was a provincial town with a modest population. This has however changed today due to urbanization. And, the major source of drinking water to people living in the Metropolis is processed water from Dadin Kowa Dam. Although the state government has made a lot of effort to ensure steady supply of this vital resource to the citizenry, but the quantity available to the people at any given time is far from being adequate. 
This is because the state's Water Board has no installed capacity to meet the city's water demand, as unfortunately, the city's development has long outstripped its distribution network. Epileptic power supplies and other supply problems that militate against water production to design schedules have also been described as impediments. This has led to a situation in which many people resolved to ' drill their own borehole or revert to the traditional hand dug wells that were used before the construction of the Dadin Kowa water treatment plant (Hati, 2011).

This study is therefore very crucial at the moment because of the rapid increase in the number of the boreholes constituting a substantial source of drinking water for public consumption in Gombe Metropolis. The level of nitrates in some part of the Metropolis that are built in reclaimed dumpsites could be high. The consumers are however not aware of such concern as they do not know, rather do not really care for since the groundwater appears clean and clear to their eyes. Worse still, many of these boreholes were constructed without due consideration to the locations of pit latrines and waste dumping sites, which could make the water more susceptible to chemical and microbial contaminants through leaching and percolation, respectively. All these, really cast heavy doubt in the minds of environmental scientists and managers on the safety of the already constructed borehole water for public consumption (Sabo et al., 2013).

Cholera and typhoid are global threat to public health and a key indicator of lack of social development (World Health Organization, 2010). There have been reported cases of cholera and typhoid fever in Gombe State in 2012 (Health news). These infections are water borne disease caused by water contamination, It is in the realization of this that it became imperative to investigate the quality of borehole water in Gombe metropolis. Knowledge on quality of private drinking water is of paramount importance; thus, there is need for periodic assessment of the quality of our water sources in order to determine their level of contamination and their safety state for human consumption. Therefore, this study aimed at assessing the quality of borehole water in Gombe metropolis microbiologically and was achieved through: determination of some pathogenic bacteria present in borehole water samples; examination of the frequency of occurrence of some bacterial pathogens present in the borehole water; determination of the safety of borehole water for human consumption in Gombe metropolis.

\section{MATERIALS AND METHODS \\ Sampling Area}

Gombe metropolis is located in the north-eastern part of Nigeria, it is situated at latitude $10^{\circ} 17^{\prime}$ 13.97" N and longitude 11 ${ }^{\circ}$ 9' 58.45" E, Gombe metropolis shares common boundary with Akko Local Government Authority in the South and West; Yamaltu-Deba to the East and Kwami to the North, Occupying an area of about $45 \mathrm{~km}^{2}$. The metropolis is divided in wards and each ward can be regarded as community, serving as the seat of administration of Gombe State. It is therefore called the State headquarters (FRN, 2007; Lazarus, 2008).

\section{Sample Collection}

A total of thirty (30) water samples were collected aseptically in triplicate in a sterile tube from some selected bore holes $(200 \mathrm{ml}$ from each borehole) in Gombe metropolis. The different locations where borehole water samples were collected are Arawa: Tudun Wada, Jauro Abare, Pantami, State low-cost, Federal low-cost, Madaki, Bolari, Chechenia and Riyadh.

Each collected borehole water sample was labeled with the temporal borehole's code number and transported in ice pack coolers containing ice cubes within 2-3 hours to the research laboratory located at Gombe State University for analyses.

\section{Enumeration of Total and Faecal Coliform Bacteria Presumptive Test}

Total and faecal coliform were enumerated by multiple tube fermentation tests (APHA, 2005). Coliform count was obtained using the three tube assay of the Most Probable Number (MPN) technique. Presumptive coliform test was carried out using MacConkey broth. The first set of three tubes had sterile $10 \mathrm{ml}$ Double Strength Lactose Broth (DSLB) and the second and third sets had $10 \mathrm{ml}$ Single Strength Lactose Broth (SSLB). All the tubes contained Durham tubes before sterilization. The three sets of the tubes received 10, 1 and $0.1 \mathrm{ml}$ of water samples using sterile pipettes. The tubes were incubated at $37^{\circ} \mathrm{C}$ for $24-48$ hours for estimation of total coliforms and at $44.5^{\circ} \mathrm{C}$ for faecal coliforms for 24-48 hours and examined for acid and gas production. Acid production was determined by colour change of the broth from reddish purple to yellow and gas production was checked for by entrapment of gas in the Durham tube. The MPN was then determined from the MPN table for the three set of tube (Dhawale and LaMaster, 2003). 
Special Conference Edition, November, 2019 Confirmed Test for Coliforms

Confirmed test was carried out by transferring a loopful of culture from a positive tube from presumptive test into a tube of Brilliant Green Lactose Bile (BGLB) broth with Durham tubes. The tubes were incubated at $37^{\circ} \mathrm{C}$ for $24-48$ hours for total coliform and $44.5^{\circ} \mathrm{C}$ for faecal coliforms and observed for gas production (Adetunde and Glover, 2010).

\section{Completed Test for Coliforms}

Completed test was carried out by streaking a loopful of broth from a positive tube onto Eosine Methylene Blue (EMB) agar plate for pure colonies. The plates were incubated at $37^{\circ} \mathrm{C}$ for 24-48 hours. Colonies developing on EMB agar were further identified as faecal coliforms (Escherichia col/). Colonies with green metallic sheen were confirmed to be faecal coliform bacteria with rods shape (Adetunde and Glover, 2010).

Isolation and Identification of the bacteriaThe result of Total Coliform and Faecal Coliform Isolates

Macroscopic Examination

The macroscopic examination for physical morphology was performed based on the size, colour, texture, pigmentation, odour and consistency).

\section{Microscopic and Biochemical Reactions}

The microscopic examination was carried out through Gram staining and biochemical tests were also carried out according to Cheesbrough (2006) and Forbes et al. (2002).

\section{Gram Staining}

This procedure was done to distinguish between gram positive isolates from gram negative, in accordance with the methods described by Forbes et al. (2002) and Cheesbrough (2006).

\section{Biochemical Tests}

Catalase, coagulase, citrate utilization, oxidase, indole, urease, motility, and Kligler Iron Agar Test (KIA) tests were the confirmatory biochemical test carried out to identify all the isolates and results were then matched with the Bergy's manual of determinative bacteriology for confirmation.

\section{RESULTS} had both the highest total coliform and faecal coliform counts with 11 and 3 MPN/100ml respectively; while sample $\mathrm{J}$ had the least with 3 and $1 \mathrm{MPN} / 100 \mathrm{ml}$ respectively as shown in Figure 1. Based on the results obtained from all the sampling sites in Figure 1, faecal coliforms were $\geq 1 \mathrm{MPN} / 100 \mathrm{ml}$.
Counts of water samples revealed that sample A

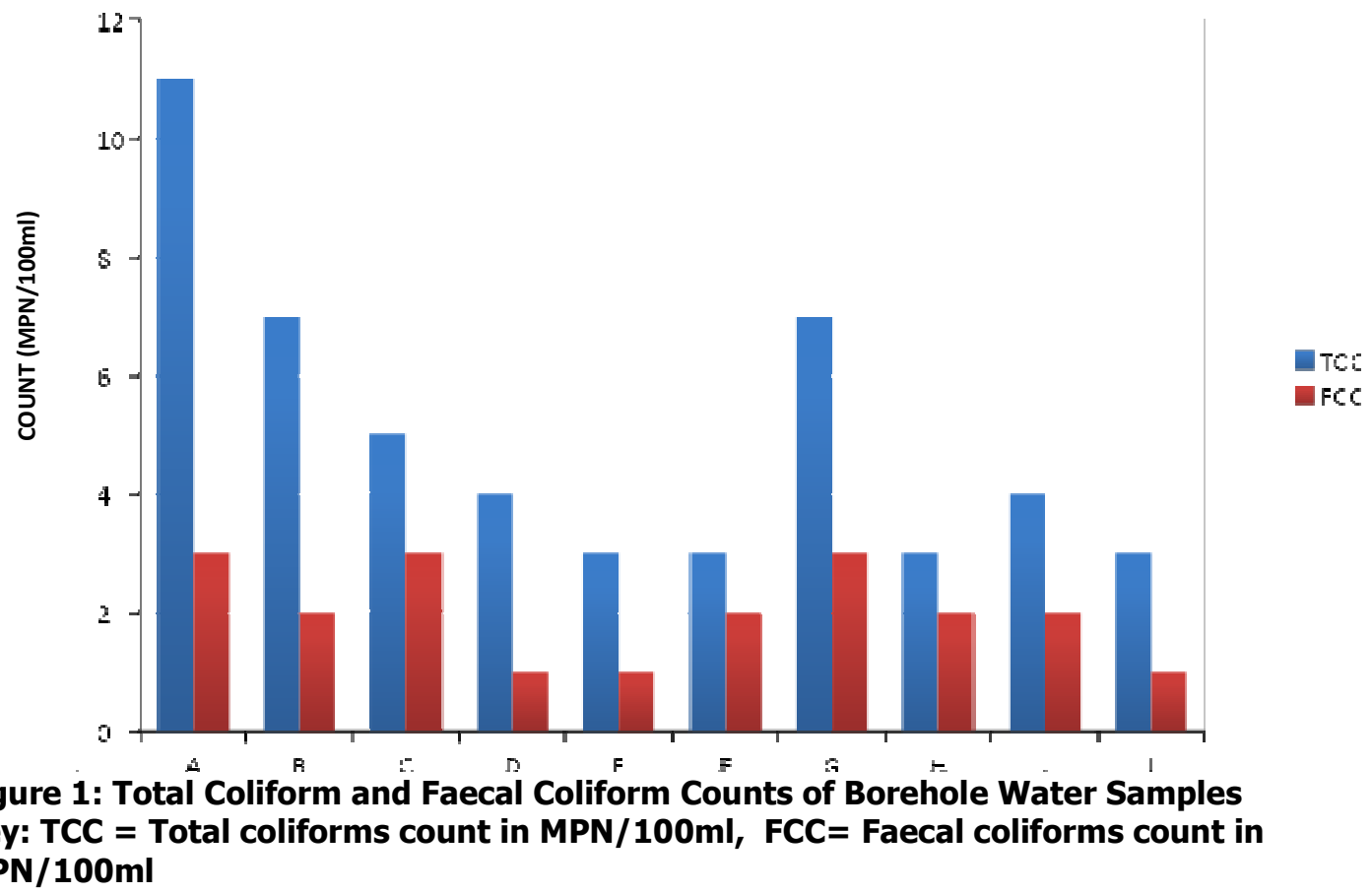

Table 2 showed variation in occurrence of bacteria isolated. The highest frequency was observed in $E$. coli and Klebsiella specie representing $26.3 \%$ and $23.7 \%$ respectively; while Salmonella and Staphylococcus aureus had the least frequencies of $14.5 \%$ and $15.8 \%$ respectively. The results indicated that $E$. coli had the highest occurrence among the bacteria isolated from all the sampling sites while Salmonella had the least occurrence. 
Special Conference Edition, November, 2019

Table 2: Frequency of Occurrence of Bacteria Isolated from Each of the Borehole Water Sample Analyzed.

\begin{tabular}{lllllllllllll}
\hline Organisms & A & B & C & D & E & F & G & H & I & J & TOTAL & \% \\
\hline Salmonella spp & 0 & 2 & 1 & 2 & 2 & 0 & 2 & 1 & 1 & 0 & 11 & 14.5 \\
E. coli & 3 & 3 & 2 & 3 & 2 & 2 & 2 & 0 & 2 & 1 & 20 & 26.3 \\
Klebsiella spp & 3 & 2 & 0 & 2 & 0 & 2 & 3 & 2 & 2 & 2 & 18 & 23.7 \\
S. aureus & 2 & 0 & 2 & 2 & 0 & 2 & 2 & 1 & 0 & 0 & 12 & 15.8 \\
Entrobacter sp. & 3 & 2 & 2 & - & 2 & 0 & 2 & 0 & 1 & 3 & 15 & 19.7 \\
Total & & & & & & & & & & & $\mathbf{7 6}$ &
\end{tabular}

Key: Key: A - Arawa, B - Tudun Wada, C - Jauro Abare, D - Pantami, E - State Low - Cost, F - Federal Low - Cost, G - Madaki, H - Bolari, I - Checheniya and J - Riyadh

\section{DISCUSSION}

Good quality water must meet internationally acceptable standards and be in line with guidelines stipulated by the World Health Organization to be fit for drinking. Water quality criteria are a function of several parameters. Appropriate parametric limits for water quality standards have been established (WHO, 2010). The present study showed the presence of aerobic heterotrophic bacteria, coliform and faecal coliform in the various borehole water samples. The study has therefore revealed the bacteriological quality of drinking water samples in Gombe metropolis.

Five pathogenic bacteria were isolated from the ten water sample analyze. These include: Salmonella spp, Escherichia coli, Klebsiella spp, Staphylococcus aureus and Entrobacter spp (Table 2). Out of the five bacteria isolated, Escherichia coli has the highest percentage of occurrence $(26.3 \%)$ followed by Klebsiella spp (23.7\%), Staphylococcus aureus (15.8\%), Entrobacter spp (19.7\%) and Salmonella $(14.5 \%)$. These Isolates with high frequency of occurrence are important human pathogens associated with a variety of infectious diseases such as gastroenteritis, typhoid fever, dysentery, cholera and urinary tract infection, (Orji et al., 2006). The high number of these pathogens in the water samples from study areas needs public health attention. The high prevalence pathogens in this study are in agreement with the findings of Obi and Okocha (2007) in selected borehole waters in World Bank Housing Estate, Umuahia and of Amajor et al (2012) on enumeration and identification of pathogenic pollution indicators in different water sources used in processing root and tuber crops in Umudike, Umuahia, Abia State, Nigeria. The presence of Escherichia coli, Staphylococcus and Enterobacter aerogenes in some of the borehole water samples are unacceptable from the public health point of view. These organisms could be pathogenic. Therefore, there is need for caution when using these contaminated borehole water sources for any purposes. Agbabiaka and Sule, (2010) obtained some members of coliform in
Ilorin (Nigeria) metropolis borehole water samples.

The Nigerian Standard for Drinking Water Quality (Adeyemi et al., 2007) recommends no faecal coliform should be found in any water meant for drinking. None of the borehole water was free of coliforms, Faecal coliform counts were highest for sample $A, C$ and $G$ with a mean value of $3 M P N / 100 \mathrm{ml}$ respectively while samples with the lowest fecal coliform counts were samples D, E and J with the mean values of $1 \mathrm{MPN} / 100 \mathrm{ml}$.

All the borehole water samples were not devoid of faecal coliform, they were however not free of total coliforms which are probably from the environmental sources and are non-faecal in origin unlike results compared from the work carried out by Ahmed et al. (2013) on the quality of wash borehole water in Gombe Metropolis, Gombe State, Nigeria. In another similar work done by Adetunde and Glover (2011) in selected secondary schools within Navrongo, Kassena-Nankana District in Uppereast Region of Ghana had higher value of total heterotrophic bacteria counts in all the samples. Most of the samples were contaminated with both nonfaecal and faecal coliform bacteria. The samples with low coliform counts could be considered to be of better quality for domestic use than the ones with the highest counts of both bacteria counts and total coliform counts (Lehloesa, 2000). McQuaig et al. (2006) and APHA, (1985) specified that potable drinking water should be devoid of total coliform in any given sample.

\section{CONCLUSION}

The results obtained in this research indicates the presence of coliforms bacteria viz; Salmonella sp., E. coli, Klebsiella sp. and Enterobacter sp. as well as Staphylococcus aureus in the water samples collected from all the study sites within Gombe metropolis. The presence of pathogenic organisms and indicator organisms in some of the water samples may renders it unfit for human consumption. 


\section{Special Conference Edition, November, 2019 RECOMMENDATIONS}

The sanitary control inspectors should insist on proper waste disposal management. There should be a continuous monitoring of borehole water by the relevant constituted authority in order to detect any changes in the water quality. More borehole systems should be constructed to replace the shallow hand-dug wells. The result of their industrial and domestic use after treatment and purification makes borehole water free from pathogenic organisms. We also recommended that the Government should ensure proper development of public community water system to ensure good quality drinking

\section{REFERENCES}

Adetunde, L.A. and Glover, R.L.K. (2010). Bacteriological Quality of Borehole Water Used by Students' of University for Development Studies, Navrongo Campus in Upper-East Region of Ghana. Current Research Journal of Biological Sciences, 2(6):361-364.

Adetunde, L.A. and Glover,R.L.K (2011). Evaluation of bacteriological quality of drinking water used by selected secondary schools in Navrongo in Kassena Nankana district of upper east region of Ghana. Prime Journals of Microbiology Research (PJMR), 1(3):4751.

Adeyemi, O., Oloyede, O.B., and Oladiji, A.T. (2007). Physicochemical and Microbial characteristics of Leachate contaminated ground water. Asian Journal Biochemistry, 2 (5):343-348.

Agbabiaka, T.O. and Sule, I.O. (2010). Bacteriological Assessment of Selected Borehole Water Samples in Ilorin Metropolis. International Journal of Applied Biological Research, 2(2):31-37.

Ahmed, S., Haruna, A. and Abubakar, U.Y. (2013): Assessment of Wash-Borehole Water Quality in Gombe Metropolis, Gombe State, Nigeria. Journal of Environment and Earth Science, 3(1)6571.

Amajor, J.U., Eleazu, C.O., Amajor, E.E., Ironua, C.F. and Nwosu, P. (2012). Comparative evaluation of the physicochemical composition and microbial quality of seven different water sources used in processing root and tuber crops in Umudike, Nigeria. African Journal of Biotechnology, 11(87):15330-15335.

American Public Health Association (APHA) (1985). Standard Methods for the Examination of water and Waste. R. R. Donnelley and sons company, United water for the community. Good drainage system should be ensured in both rural and urban communities to avoid sewage contaminating ground water. The Government should engage in recycling of waste through generation of biofuel. This will minimize contamination of ground water. Further research such as algal test should be conducted to ascertain the quality of borehole water hence detects algae and algal toxins in borehole water samples. Further research should also be carried out at different seasons of the year and in more boreholes to ascertain more quality of borehole water systems.

States of America, 16th ed. 1027$1064 \mathrm{pp}$.

American Public Health Association (APHA) (2005). Standard Methods for the Examination of water and Wastewater. 21st ed. American Public Health Association, Washington DC, 12-20.

Cheesbrough, M. (2006). District Laboratory Practice in Tropical Countries, part 2, Cambridge Press UK, 5-541.

Dhawale, S. and LaMaster, A. (2003). Microbiology Laboratory Manual. The McGraw Companies Incorporation, USA, p187.

Federal Republic of Nigeria (FRN). (2007). Official Gazette: Legal Notice on Publication of the 2006 Census Report, 4(94) B, pp. 185-186. Lagos, Nigeria[Online] http://www.mapsofworld.com/lat long/n igeria-lat-long.html.

Forbes, J. A., Stone, J. D., Parthasarathy, S., Toutonghi, M. J. and Sliger, M. V. (2002). U.S. Patent No. 6,381,742. Washington, DC: U.S. Patent and Trademark Office.

Larry, W. (2006): World Water Day: A Billion people Worldwide Lack Safe Drinking [Online]

http://www.environment.about.com/od/ environmentalevents/ a/waterdayqa.htm. March 22nd, 2006.

Lazarus, A. M. (2008). Analysis of water consumption pattern among residential areas in Gombe Metropolis. Continental Journal of Applied Sciences, 3, 77-84.

Lehloesa, N. Y. O. (2000). Evaluation of the impact of household treatment procedures on the quality of groundwater supplies in the rural community of the Victoria district, Eastern Cape. Water SA, 26(2), 285290. 
McQuaig, S. M., Scott, T. M., Harwood, V. J., Farrah, S. R., and Lukasik, J. O. (2006). Detection of human-derived fecal pollution in environmental waters by use of a PCR-based human polyomavirus assay. Applied and environmental microbiology, 72(12), 7567-7574.

Obi, C.N. and Okocha, C.O. (2007). Microbiological and Physcio-Chemical Analysis of Selected Bore-hole Waters in World Bank Housing Estate, Umuahia, Abia State, Nigeria. Journal of Engineering and Applied Sciences, 2(5):920-929.

Orji, M.U., Ezenwaje, E.E., Anyaegbunam BC (2006): Spatial appraisal of shallow well water pollution in Awka, Nigeria.
Nigerian Journal of Microbiology, 20(3):1389-1384.

Sabo, A., Adamu, H. and Yuguda, A. U. (2013). Assessment of Wash-Borehole Water Quality in Gombe Metropolis, Gombe State, Nigeria. Assessment, 3(1).

Steiner, T.S., Samie, A. and Guerrant, R.L. (2006): Infectious diarrhea: new pathogens and new challenges in developed and developing areas. Clinical Infectious Diseases, 43:408-410.

World Health Organization (WHO). (2010). Guidelines for Drinking water Quality. Recommendation. Pp1-6, Geneva Switzerland. [Online] http://www.who.int/water_sanitation_he alth/WHS WWD2010 guidelines 2010 $\underline{6 \text { en }}$ 